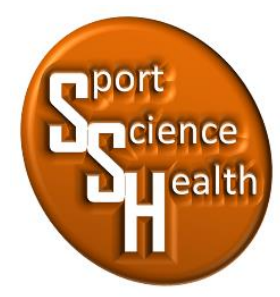

ISSN 2715-3886

\title{
Hubungan Antara Kekuatan Otot Tungkai Dan Koordinasi Dengan Keterampilan Passing
}

\author{
Ayutisa Rizqanada1*, Mashuri Eko Winarno² \\ 1,2Jurusan Pendidikan Jasmani Kesehatan dan Rekreasi, Fakultas IImu Keolahragaan, \\ Universitas Negeri Malang, Jalan Semarang No. 5, Malang, Jawa Timur, 65145, Indonesia \\ *Penulis koresponden: ayutisa1309@gmail.com, +6281217619862
}

\begin{abstract}
The purpose of this study was to determine the tendency of the relationship between leg muscle strength and coordination with the passing skills of Arema U-14 Academy students. This study uses a correlational method with the research subjects of Arema U-14 Academystudents totaling 30 students. Based on the results of the analysis shows that; 1 ) there is a relationship between strength and passing skills with $r_{\text {court }}$ $\left.(0.406)<r_{\text {table }}(0.361), 2\right)$ there is a relationship between coordination and dribbling skills with $r_{\text {count }}(0.382)<r_{\text {table }}$ $(0.361)$, and 3$)$ there is a relations hip between strength and coordination with passing skills with $R_{y . x 122}(0.595)>$ $r_{\text {table }}(0.361)$. The conclusion from this study there is a relationship between leg muscle strength and coordination with passing skills.
\end{abstract}

Keyword: leg muscle strength; coordination; passing skills

Abstrak:Tujuan penelitian ini adalah untuk mengetahui kecenderungan hubungan antara kekuatan otottungkai dan koordinasi dengan keteram pilan passing siswa Akademi Arema U-14. Penelitian ini menggunakan metode korelasional dengan subjek penelitian siswa Akademi Arema U-14 berjumlah 30 siswa. Berdasarkan hasil analisis menunjukkan bahwa; 1 ) terdapat hubungan antara kekuatan dengan keterampilan passing dengan $\mathrm{rhitur}$ $(0,406)<\mathrm{rtabel}(0,361), 2)$ terdapat hubungan antara koordinasi dengan keterampilan dribbling dengan $\mathrm{r}_{\text {hitung }}$ $(0,382)<$ rabel $(0,361)$, dan 3$)$ terdapathubungan antara kekuatan dan koordinasi dengan keterampilan passing dengan $R_{y \times 1 \times 2}(0,595)>r_{\text {tabel }}(0,361)$. Kesimpulan dari penelitian ini terdapat hubungan antara kekuatan otot tungkai dan koordinasi dengan keterampilan passing.

Kata kunci: kekuatan otot tungkai; koordinasi; keterampilan passing

\section{PENDAHULUAN}

Sepakbola adalah permainan bola besar yang dimainkan oleh 11 orang yang berusaha memasukkan bola ke gawang lawan untuk memperoleh kemenangan. Prinsip dalam sepakbola adalah membuat gol sebanyak mungkin ke gawang lawan dan mencegah lawan jangan sampai mencetak gol ke gawang yang telah dipertahankan.Keterampilan dasar yang harus dikuasai dalam bermain sepakbola adalah mengumpan (passing), menahan bola (control), menggiring bola (dribbling), dan menendang bola (shooting) (Anwari, 2016). Dalam sepakbola terdapat beberapa komponen fisik yang harus dimiliki oleh setiap pemain sepakbola, seperti kekuatan (strength), daya tahan (endurance), daya ledak (power), kecepatan (speed), daya lentur (flexibility), kelincahan (agility), koordinasi (coordination), keseimbangan (balance), ketepatan (accuracy), dan reaksi (reaction) (Nuzzo, 2020). Dengan kemapuan/kondisi fisik yang baik maka saat menampilkan kemampuan mengumpan bola (passing) akan terlihat lihai dan sempurna. Kekuatan adalah kemampuan otot 
untuk melakukan kontraksi yang berguna membangkitkan ketegangan terhadap suatu tahanan (Lloyd \& Oliver, 2012).

Kekuatan merupakan daya penggerak setiap aktivitas yang dilakukan oleh manusia dan merupakan salah satu komponen penting untuk meningkatkan skill dalam berolahraga untuk mencapai prestasi yang baik. Karena dengan kekuatan seorang pemain akan dapat mengumpan bola dengan baik dengan kekuatan yang dimiliki kepada rekan setimnya (selain ditunjang dengan faktor teknik bermain yang baik) dan selain itu dengan memiliki kekuatan yang baik dalam sepakbola, pemain dapat melakukan tendangan keras dalam usaha untuk mengumpan daerah kepada teman maupun untuk mencetak gol (Mu'is \& Widodo, 2014). Unsur koordinasi ini juga mempunyai peran yang penting dalam melakukan passing.

Koordinasi adalah kemampuan seseorang mengintegrasikan bermacam-macam gerakan yang berbeda ke dalam pola gerakan tunggal. Koordinasi menyatakan hubungan harmonis berbagai faktor yang terjadi pada suatu gerakan. Koordinasi dalam sepakbola ini adalah kemampuan menyelaraskan beberapa gerakan dengan memanfaatkan beberapa komponen kondisi fisik menjadi pola gerakan tunggal efektif dalam memaksimalkan kemampuan bermain sepakbola (Ashari \& Adi, 2019). Hubungan koordinasi dan kekuatan terhadap kemampuan mengumpan bola (passing) adalah menciptakan serangkaian gerakan yang berkesinambungan. Sehingga koordinasi berpengaruh ketika pemain memberikan umpan dan menerima umpan dari rekan satu timnya ketika berlari mencari ruang gerak di area pertahanan lawan.

\section{Sepakbola}

Sepakbola adalah permainan yang dilakukan oleh dua kelompok pemain yang terdiri dari 11 orang dengan menggunakan bola sepak dan kaki sebagai alat penendangnya (Pertiwi \& Murbawani, 2012). Sepakbola merupakan permainan beregu yang memerlukan dasar kerja sama antar pemain dalam menjalankan strategi permainan untuk memenangkan sebuah pertandingan (Taufik, 2017). Dalam bemain sepakbola, seorang pemain harus menguasai beberapa teknik dasar bermain sepakbola seperti menendang bola (shooting), mengontrol bola (controling), menyundul bola (heading), menggiring bola (dribbling), melempar bola (throw in), merebut bola (feinting), dan teknik menjaga gawang (goalkeeper) (Saputra, 2016).Teknik passing sangatlah penting dan sering digunakan dalam permainan sepakbola tersebut. Mengumpan bola merupakan kemampuan yang harus dimiliki oleh setiap pemain karena passing bisa digunakan untuk mengatur tempo permainan bahkan menyiapkan strategi penyerangan ke daerah lawan untuk mencetak gol pada gawang lawan.

\section{Keterampilan Mengumpan Bola (Passing)}

Menurut Kurniawan, Nurrochmah, \& H Paulina (2016) dalam sepakbola, hal yang paling mendominasi adalah mengoper bola. Mengoper dapat juga diartikan sebagai pergerakan memindahkan bola dari kaki pemain yang satu ke pemain yang lainnya (Amansya \& Sinaga, 2015). Dari beberapa pendapat ahli diatas dapat disimpulkan bahwa, passing merupakan suatu teknik dasar dalam sepakbola dimana bola berpindah dari kaki pemain yang satu ke pemain yang lainnya dalam satu tim itu sendiri. Untuk bisa melakukan passing dengan baik, tentunya seorang pemain harus menguasai gerakan teknik dasar sepakbola secara benar dan berlatih secara giat. Passing dalam sepakbola dibedakan menjadi 3 yaitu, passing dengan kaki bagian dalam, passing dengan punggung kaki, dan passing kak bagian luar. Dapat disimpulkan bahwa passing merupakan kemampuan teknik dasar yang harus dimiliki oleh pemain sepakbola dalam memberikan umpan atau operan kepada pemain lain dalam rekan satu timnya yang dapat dilakukan dengan cara mengumpan menggunakan seluruh anggota badan kecuali bagian tangan.

\section{Kekuatan Otot Tungkai (Leg Muscle Strength)}

Kekuatan adalah komponen fisik dasar yang harus dimiliki oleh setiap atlet dan berhubungan dengan kualitas gerak suatu atlet. Kekuatan secara fisiologi merupakan kemampuan otot atau sekelompok otot untuk melakukan satu kali kontraksi secara maksimal melawan tahanan atau beban (Ashari \& Adi, 2019). Kekuatan menurut (Mansur, et al., 2009) dibagi menjadi 3 yaitu a) kekuatan maksimal (maximal strength), b) daya tahan kekuatan (strength endurance), c) kekuatan yang cepat (power). Kekuatan maksimal adalah kekuatan yang diperoleh oleh seorang atlet dalam berbagai latihan untuk mencapai kualitas kekuatan yang baik. Yang dimaksud dalam kekuatan otot tungkai ini adalah kekuatan otot yang terdapat pada tungkai seseorang sehingga dapat menghasilkan tenaga dalam melakukan aktivitas passing seakbola. Menurut Zulfa \& Kurniawan (2020) kekuatan otot tungkai merupakan suatu usaha kemampuan otot untuk menerima beban dan 
memberikan suatu kontraksi otot untuk mengerahkan kekuatan pada tungkai seseorang pemain dalam waktu tertentu. Dapat disimpulkan bahwa kekuatan otot tungkai merupakan unsur kondisi fisik untuk daya penggerak setiap aktivitas dan bekerja sekali kontraksi untuk melawan tahanan dan beban khusus.

\section{Koordinasi (Coordination)}

Koordinasi adalah kemampuan untuk melakukan gerakan dengan berbagai tingkat kesulitan dengan cepat, efisien, penuh ketepatan dan merangsang bekerjanya suatu otot pada saat seseorang menghentikan rangsangan yang berlawan dengan otot itu (Hakim, 2018). Koordinasi adalah suatu kemampuan biomotorik yang kompleks dan erat kaitannya dengan kemampuan fisik lainnya. Kemampuan tersebut digunakan untuk mengendalikan dan menggabungkan bagian tubuh lainnya yang dilibatkan dalam model gerakan yang kompleks, dengan urutan yang benar dan menggabungkan bagian-bagian tersebut dalam suatu model gerakan yang lancar. Dalam permainan sepakbola koordinasi antara mata dan kaki menjadi hal mutlak dalam bermain sepakbola. Ketika pemain mengumpan bola, mata adalah pusat dimana pandangan atau arah untuk mengetahui kondisi sekitar lapangan yang dilihat, sedangkan kaki berperan sebagai pengolah bola saat melakukanpermainan di lapangan. Sehingga koordinasi akan terlihat ketika pemain dapat mempertahankan bola saat mengumpan bola. Hal ini juga dibuktikan dari hasil penelitian yang menujukkan bahwa memiliki koordinasi mata-kaki yang baik maka kemampuan passing akan meningkat (Fahrizqi, 2018). Dalam permainan sepakbola dibutuhkan kecermatan pandangan dalam mengantisipasi bola dan ketepatan gerak untuk menendang bola atau memberikan umpan sesuai sasaran.

\section{METODE}

Rancangan penelitian yang digunakan dalam penelitian ini adalah deskriptif menggunakan pendekatan kuantitatif. Untuk menguatkan data penelitian ini, peneliti menggunakan jenis penelitian kuantitatif berupa tes, karena data yang diperoleh dalam penelitian ini merupakan data angka. Sedangkan teknik analisisnya menggunakan analisis korelasional. Teknik analisis korelasi yang digunakan adalah korelasi Product Moment dari Person, karena untuk menentukan kecenderungan hubungan antara dua variabel interval atau rasio. Subjek dalam penelitian ini adalah siswa Akademi Arema U-14 yang berjumlah 30 anak. Penelitian ini menggunakan instrumen sesuai dengan variabel yang diteliti, berupa: 1) leg dynamometer test yang digunakan untuk mengukur kekuatan otot tungkai, 2) mitchel soccer test yang digunakan untuk mengukur koordinasi, dan 4) passing and stopping test yang digunakan untuk mengukur keterampilan mengumpan bola.

HASIL

Data hasil penelitian yang digunakan untuk analisis adalah skor hasil tes kecepatan, kelincahan, koordinasi dan keterampilan menggiring bola siswa Akademi Arema U-14. Deskripsi data hasil penelitian tersebut disajikan pada tabel 4.1 berikut ini.

Tabel 1. Deskripsi Data Hasil Tes Kekuatan Otot Tungkai, Koordinasi, dan Keterampilan Passing

\begin{tabular}{ccccc}
\hline Variabel & $\mathbf{n}$ & Jumlah & Mean & Standart Deviasi \\
\hline $\mathrm{X}_{1}$ & 30 & 1458,5 & 50,72 & 17,11 \\
$\mathrm{X}_{2}$ & 30 & 447 & 14,9 & 1,60 \\
$\mathrm{Y}$ & 30 & 200 & 6,67 & 1,12 \\
\hline
\end{tabular}

Keterangan:

$\mathrm{X}_{1} \quad$ : Variabel bebas kekuatan otot tungkai.

$X_{2} \quad$ : Variabel bebas koordinasi.

Y : Variabel terikat keterampilan passing.

Berdasarkan data pada tabel 1 data tersebut memiliki jenis dan satuan yang berbeda-beda maka data kekuatan, koordinasi dan keterampilan passing harus diubah menjadi angka standar dengan menggunakan Tskor agar data dapat ditambah dan dikurangi dalam penghitungan. 


\section{Uji Persyaratan Analisis}

Hasil Uji Normalitas

Tabel 2 Hasil Uji Normalitas Data

\begin{tabular}{cccc}
\hline Variabel & Hasil Analisis & Nilai Tabel L (0,05) & Keterangan \\
\hline$X_{1}$ & 0,112 & 0,161 & Lhitung $<$ Ltabel $($ normal) \\
$X_{2}$ & 0,125 & 0,161 & Lhitung $<$ Ltabel $($ normal) \\
$Y$ & 0,157 & 0,161 & Lhitung $<$ Ltabel (normal) \\
\hline
\end{tabular}

Berdasarkan tabel 2 di atas menunjukkan bahwa semua variabel dalam penelitian ini berdistribusi normal.

Uji Linieritas

Tabel 3 Hasil Uji Linieritas

\begin{tabular}{cccc}
\hline Variabel & $\mathbf{F}_{\text {hitung }}$ & $\mathbf{F}_{\text {tabel }}$ & Keterangan \\
\hline$X_{1} Y$ & 0,370 & 5,77 & $F_{\text {hitung }}<F_{\text {tabel }}$ (linier) \\
$X_{2} Y$ & 1,223 & 2,55 & Fhitung $<$ Ftabel (linier) \\
\hline
\end{tabular}

Berdasarkan tabel 3 di atas menunjukkan bahwa setiap variabel bebas dalam penelitian ini memiliki hubungan yang linier dengan variabel terikat.

Uji Hipotesis

Persamaan Regresi

Tabel 4 Hasil Persamaan Regresi

\begin{tabular}{lc}
\hline & Unstandardized Coefficients \\
\cline { 2 - 2 } Model & $\mathbf{B}$ \\
\hline Constant (bo) & 5,128 \\
Kekuatan (b1) & 0,459 \\
Koordinsi (b2) & 0,438 \\
\hline
\end{tabular}

Berdasarkan hasil tabel 4 di atas menunjukkan bahwa nilai regresi keterampilan passing $(Y)$ atas kekuatan $\left(X_{1}\right)$, dan koordinasi $\left(\mathrm{X}_{2}\right)$ adalah $\hat{\mathrm{Y}}=5,128+0,459 \mathrm{X}_{1}+0,438 \mathrm{X}_{2}$.

\section{Korelasi Sederhana Antar Variabel}

Tabel 5 Hasil Penghitungan Korelasi antara Variabel Bebas dengan Variabel Terikat

\begin{tabular}{|c|c|c|c|}
\hline Variabel & rhitung & $\mathbf{r}_{\text {tabel }}$ & Keterangan \\
\hline$X_{1} Y$ & 0,406 & 0,361 & $\begin{array}{c}\text { rhitung }>\text { rtabel } \\
\text { (terdapat hubungan) }\end{array}$ \\
\hline$X_{2} Y$ & 0,382 & 0,361 & $\begin{array}{c}\text { rhitung }>\text { rtabel } \\
\text { (terdapat hubungan) }\end{array}$ \\
\hline
\end{tabular}

Berdasarkan tabel 5 di atas menunjukkan bahwa setiap variabel bebas dalam penelitian ini tidak memiliki hubungan dengan variabel terikat 


\section{Korelasi Ganda}

Tabel 6 rangkuman hasil penghitungan koefisien korelasi antara kekuatan dan koordinasi dengan keterampilan passing

\begin{tabular}{ccccccccc}
\hline \multirow{2}{*}{$\mathbf{R}$} & \multirow{2}{*}{$\boldsymbol{R}_{\text {square }}$} & \multirow{2}{*}{$\begin{array}{c}\text { Adjusted } \boldsymbol{R} \\
\text { Square }\end{array}$} & $\begin{array}{c}\text { Std. Error of the } \\
\text { Estimate }\end{array}$ & $\begin{array}{c}\boldsymbol{R} \text { Square } \\
\text { Change }\end{array}$ & $\begin{array}{c}\boldsymbol{F} \\
\text { Change }\end{array}$ & df1 df2 & $\begin{array}{c}\text { Sig. } \boldsymbol{F} \\
\text { Change }\end{array}$ \\
\hline $.595^{\mathrm{a}}$ & .354 & .306 & 8.32982 & .354 & 7.398 & 2 & 27 & .003 \\
\hline
\end{tabular}

a. Predictors: (Constant), Koordinasi, Kekuatan

Berdasarkan tabel 6 di atas menunjukkan bahwa variabel bebas dalam penelitian ini memiliki hubungan secara bersama-sama dengan variabel terikat.

\section{Regresi Ganda}

Tabel 7 Hasil Perhitungan Statistik Regresi

\begin{tabular}{ccccc}
\hline \multicolumn{5}{c}{ Model Summary } \\
\hline $\mathbf{R}$ & $\boldsymbol{R}$ square & Adjusted $\boldsymbol{R}$ Square & Standard Error & Observations \\
\hline 0.595 & 0.354 & 0.306 & 8.32982 & 30 \\
\hline
\end{tabular}

Berdasarkan tabel 7 di atas menunjukkan bahwa besarnya sumbangan semua variabel bebas terhadap variabel terikat sebesar $35,4 \%$ dan sisahnya dipengaruhi variabel lain. Hasil analisis regresi tersebut dirangkum dan disajikan dalam tabel berikut,

Tabel 8 Rangkuman Hasil Analisis Regresi

\begin{tabular}{lccccc}
\hline \multicolumn{7}{c}{ ANOVA $^{\boldsymbol{b}}$} \\
\hline Model & Sum of Squares & df & Mean Square & F & Sig. \\
\hline Regression & 1026.595 & 2 & 513.297 & 7.398 & $.003^{\text {b }}$ \\
Residual & 1873.418 & 27 & 69.386 & & \\
Total & 2900.013 & 29 & & & \\
\hline
\end{tabular}

a. Predictors: (Constant), Koordinasi, Kekuatan

b. Dependent Variable: Passing

Berdasarkan tabel 8 di atas menunjukkan bahwa semua variabel bebas dalam penelitian ini memiliki hubungan yang signifikan secara bersama-sama dengan variabel terikat.

\section{Sumbangan Efektif dan Sumbangan Relatif}

Tabel 9 Hasil Penghitungan Sumbangan Efektif dan Sumbangan Relatif

\begin{tabular}{ccc}
\hline Variabel & Sumbangan Efektif & Sumbangan Relatif \\
\hline$X_{1}$ & $18,64 \%$ & $52,69 \%$ \\
$X_{2}$ & $16,73 \%$ & $47,31 \%$ \\
\hline
\end{tabular}

Berdasarkan tabel 9 di atas menunjukkan bahwa kelincahan memiliki sumbangan efektif dan sumbangan relatif paling besar daripada variabel lainnya.

\section{Uji Hipotesis}

Berdasarkan hasil analisis data yang dilakukan antara variabel bebas kekuatan dengan variabel terikat keterampilan paasing diperoleh tabel Nilai koefisien korelasi $r$ sebesar 0,406 > dari rtabel sebesar 0,361 maka $\mathrm{Ha}$ diterima. Berdasarkan hasil analisis data yang dilakukan antara variabel bebas koordinasi dengan variabel terikat keterampilan passing diperoleh nilai koefisien korelasi $r$ sebesar 0,382 > dari rtabel sebesar 0,361 maka $\mathrm{Ha}$ diterima. Berdasarkan hasil analisis data yang dilakukan antara variabel bebas kekuatan dan variabel bebas 
koordinasi dengan variabel terikat keterampilan passing diperoleh nilai koefisien korelasi $\mathrm{R}$ sebesar 0,595 > dari rtabel sebesar 0, 361 maka $\mathrm{H}_{0}$ ditolak dan $\mathrm{Ha}_{\mathrm{a}}$ diterima.

\section{PEMBAHASAN}

\section{Hubungan antara Kekuatan Otot Tungkai dengan Keterampilan Passing}

Uji hipotesis yang pertama "terdapat hubungan antara kekuatan dengan keterampilan passing pemain Akademi Arema U-14". Hasil uji hipotesis dengan menggunakan analisis korelasi. Berdasarkan analisis tersebut diperoleh koefisien korelasi antara kekuatan dengan passing sebesar $R=0,406$ yang artinya makin besar koefiesen korelasi yang memeengaruhi, makan besar pengaruh dari variable tersebut. Uji keberartian koefisien korelasi tersebut dilakukan dengan cara meembandingkan nilai rhitung dengan rtabel sebesar 0,361, Karena koefisien korelasi antara $r \times 1 . y=0,406>$ rtabel $=0,361$, dengan begitu artinya koefisien korelasi tersebut signifikan. Artinya $\mathrm{H}_{0}$ ditolak $\mathrm{H}_{a}$ diterima, sehingga dapat disimpulkan bahwa variable kekuatan terdapat hubungan yang signifikan dengan keterampilan passing.

Nilai sumbangan efektif yang diberikan oleh variabel kekuatan dengan variabel keterampilan passing sebesar $18,64 \%$. Hal ini juga disampaikan oleh penelitian sebelumnya yang menyatakan bahwa kekuatan otot tungkai memiliki hubungan sebesar 51,8\% dengan jauhnya tendangan (Weda \& Harmono, 2018:37). Terdapat hubungan yang signifikan antara kekuatan otot tungkai dengan keterampilan passing dengan korelasi $r$ sebesar 0,462 >0,361 rtabel (Wibowo, 2018). Terdapat hubungan yang signifikan antara kekuatan otot tungkai dengan keterampilan passing sebesar 27,30 > 3,35 (Ginanjar, 2018). Dengan ini bahwa apabila seorang pemain sepakbola memiliki kekuatan yang bagus maka dalam melakukan teknik dasar passing akan bagus pula dikarenakan teknik dasar passing juga membutuhkan kekuatan dalam mengumpan bola.

\section{Hubungan antara Koordinasi mata dan Kaki dengan Keterampilan Passing}

Uji hipotesis yang kedua "terdapat hubungan antara keoordinasi dengan keterampilan passing pemain Akademi Arema U-14". Hasil uji hipotesis dengan menggunakan analisis korelasi. Berdasarkan analisis tersebut diperoleh koefisien korelasi antara kekuatan dengan passing sebesar $R=0,382$ yang artinya makin besar koefiesen korelasi yang memeengaruhi, makan besar pengaruh dari variabel tersebut. Uji keberartian koefisien korelasi tersebut dilakukan dengan cara meembandingkan nilai rhitung dengan rtabel sebesar 0,361, Karena koefisien korelasi antara $r_{x 1 . y}=0,382>$ rtabel $=0,361$, dengan begitu artinya koefisien korelasi tersebut signifikan. Artinya $\mathrm{H}_{0}$ ditolak $\mathrm{H}_{a}$ diterima, sehingga dapat disimpulkan bahwa variable koordinasi terdapat hubungan yang signifikan dengan keterampilan passing.

Nilai sumbangan efektif yang diberikan oleh variabel kekuatan dengan variabel keterampilan passing sebesar $16,73 \%$. Hal ini juga disampaikan oleh penelitian sebelumnya yang menyatakan bahwa besarnya kontribusi koordinasi mata-kaki dengan kemampuan passing sebesar 52.99\% (Fahrizqi, 2018:39). Terdapat hubungan yang signifikan antara koordnasi mata dan kaki dengan keterampilan passing dengan korelasi koefisien $r$ sebesar 27,30 > 3,35 (Ginanjar, 2018). Dengan ini bahwa apabila seorang pemain sepakbola mempunyai koordinasi yang baik dan mumpuni maka dalam melakukan teknik dasar passing seorang pemain sepakbola maka tentu akan berpengaruh untuk memberikan hasil yang optimal terhadap kemampuan menendang bola pada permainan sepakbola.

\section{Hubungan antara Kekuatan dan Koordinasi dengan Keterampilan Passing}

Uji hipotesis yang ke tiga adalah "terdapat hubungan antara kekuatan dan koordinasi dengan keterampilan passing atlet Akademi Arema U-14". Hasil uji hipotesis dengan menggunakan analisis korelasi.

Berdasarkan analisis tersebut diperoleh koefisien korelasi antara kekuatan dan koordinasi dengan keterampilan passing sebesar $R=0,595$ artinya makin besar nilai koefisien korelasi yang mempengaruhi, maka makin besar pengaruhnya. Uji keberartian koefisien korelasi tersebut dilakukan dengan cara membandingkan nilai rhitung dengan rtabel dengan a taraf signifikan 0,05 dan $\mathrm{N}=30$ diperoleh nilai rtabel sebesar 0,361 . Karena koefisien korelasi antara $r_{x} \times 2 . y=0,595>$ rtabel $=0,361$, berarti koefisien korelasi tersebut signifikan. Artinya $\mathrm{H}_{0}$ ditolak dan $\mathrm{H}_{a}$ diterima, sehingga dapat disimpulkan bahwa terdapat hubungan yang signifikan antara kekuatan dan koordinasi dengan keterampilan passing. 
Besarnya hubungan antara kekuatan dan koordinasi dengan kemampuan passing atlet Akademi Arema U-14 diketahui dengan cara nilai Adjusted $R$ square x $100 \%$. Nilai yang diperoleh sebesar 0,306 sehingga besarnya sumbangan sebesar $30,6 \%$, sedangkan sisanya dipengaruhi oleh faktor lain.

Dari hasil tersebut menunjukkan bahwa kekuatan dan koordinasi berpengaruh terhadap keterampilan passing. Oleh karena itu teknik menyepak bola (passing) harus terus menerus dilatih dengan kontinyu dan bertahap untuk memperoleh dasar keterampilan menyepak bola dengan baik. Setelah melakukan latihan keterampilan passing maka seorang pemain juga harus melatih kemampuan fisiknya seperti unsur kekuatan dan koordinasi yang dapat memberikan pengaruh terhadap kemampuan menyepak bola. Pemain yang memiliki keterampilan dasar menyepak bola yang baik dan memiliki unsur kondisi fisik yang baik pula dalam unsur kondisi fisik kekuatan dan kooridnasi kemungkinan tidak akan kesulitan saat melatih kemampuan passingnya dengan metode latihan yang diberikan oleh pelatih yang membutuhkan kombinasi dari kedua unsur kondisi fisik tersebut. Sehingga pemain dapat menyempurnakan kemampuan menyepak bolanya agar lebih terampil saat bermain di lapangan maupun saat latihan.

\section{KESIMPULAN}

Berdasarkan hasil penelitian yang berjudul Hubungan Antara Kekuatan dan Koordinasi Terhadap Keterampilan Passing Atlet Akademi Arema U-14 dapat diraih kesimpulan sebagai berikut: 1) kekuatan otot tungkai memiliki hubungan yang signifikan dengan keterampilan passing atlet Akademi Arema U-14, 2) koordinasi memiliki hubungan yang signifikan dengan keterampilan passing atlet Akademi Arema U-14, 3) terdapat hubungan yang signifikan antara kekuatan otot tungkai dan koordinasi mata dan kaki dengan keterampilan passing atlet Akademi Arema U-14.

\section{Ucapan Terima Kasih}

Peneliti menyadari, bahwa dalam penulisan skripsi ini tidak akan selesai tanpa bantuan dari berbagai pihak, sehingga diksempatan yang baik peneliti mengucapkan terimakasih yang sebesar-besarnya kepada Dr. Sapto Adi, M.Kes., selaku Dekan Fakultas IImu Keolahragaan Universitas Negeri Malang, yang telah memberikan kesempatan bagi peneliti untuk menyelesaikan pendidikan dan menempuh jenjang sarjana di FIK UM, Dr. dr. Moch. Yunus, M.Kes., selaku Wakil Dekan I Fakultas IImu Keolahragaan yang telah membantu dan memberikan izin dalam proses penelitian, Dr. Lokananta Teguh Hari Wigunao, M.Kes., selaku Ketua Jurusan Pendidikan Jasmani dan Kesehatan Fakultas IImu Keolahragaan, Prof. Dr. M. E. Winarno. M.Pd., selaku dosen pembimbing skripsi yang telah meluangkan waktu memberikan bimbingan, motivasi, masukan dan saran-saran yang sangat berharga bagi peneliti, Bapak Dicky Firasat selaku pelatih dari tim Akademi Arema U-14 dan semua siswa Akademi Arema U-14 yang telah membantu dalam penelitian.

\section{DAFTAR PUSTAKA}

Amansya \& Sinaga. (2015). Upaya Meningkatkan Hasil Passing Melalui Variasi Latihan Berbalik Dan Mengoper Bola Pada Atlet Sepak Bola Usia 13-15 Tahun Di Ssb Sinar Pagi. Jurnal Ilmu Keolahragaan.

Anwari, A. S. (2016). Hubungan Antara Koordinasi Mata Kaki, Kekuatan Otot Tungkai, dan Kelincahan Terhadap Keterampilan Menggiring Bola Pada Peserta Ekstrakurikuler Sepakbola Di SMK YAPPI Wonosari. Jurnal Pendidikan Jasmani Dan Kesehatan, 1-9.

Ashari, R. F., \& Adi, S. (2019). Pengembangan Model Latihan Menyerang Futsal Menggunakan Formasi 3-1. Sport Science and Health, 1(2), 110-115. Retrieved from http://journal2.um.ac.id/index.php/jik/article/view/10628/4791

Fahrizqi, E. B. (2018). Hubungan Panjang Tungkai , Power Tungkai Dan Koordinasi Mata-Kaki Dengan Kemampuan Passing Pada Pemain Unit Kegiatan Mahasiswa Olahraga Futsal Perguruan Tinggi Teknorat. Journal of S.P.O.R.T, 2(1), 32-42.

Ginanjar, U. (2018). Hubungan Antara Kekuatan Otot Tungkai Dan Koordinasi Mata - Kaki Terhadap Longpass Dalam Permainan Sepakbola Diekstrakurikuler Mts Yasti Cisaat Kabupaten Sukabumi Tahun 
2018. 226-230.

Hakim, N. (2018). Pengaruh Kelincahan, Kecepatan Lari dan Koordinasi Mata-Kaki Terhadap Kemampuan Menggiring Bola Pada Permainan Sepakbola Siswa Smpn 4 Takalar.

Kurniawan, D., Nurrochmah, S., \& H Paulina, F. (2016). Hubungan Antara Kecepatan Lari Dengan Kemampuan Menggiring Bola Sepak Pada Siswa Usia 13-14 Tahun Ssb Unibraw 82 Malang. Pendidikan Jasmani.

Lloyd, R. S., \& Oliver, J. L. (2012). The youth physical development model: A new approach to long-term athletic development. Strength and Conditioning Journal. https://doi.org/10.1519/SSC.0b013e31825760ea

Mu'is, \& Widodo. (2014). Analisis Kondisi Fisik Terhadap Keterampilan Menendang Bola Ke Arah Gawang (Shooting). Jurnal Kesehatan Olahraga, 2(3), 111-121.

Nuzzo, J. L. (2020). The Case for Retiring Flexibility as a Major Component of Physical Fitness. Sports Medicine. https://doi.org/10.1007/s40279-019-01248-w

Pertiwi, A. B., \& Murbawani, E. A. (2012). Pengaruh Asupan Makan (Energi, Karbohidrat, Protein dan Lemak) Terhadap Daya Tahan Jantung Paru (Vo2 Maks) Atlet Sepak Bola. Journal of Nutrition College. https://doi.org/10.14710/jnc.v1i1.677

Saputra, W. D. (2016). Hubungan Kekuatan Otot Tungkai dan Kecepatan Terhadap Kemampuan Shooting Dalam Permainan Sepakbola Pada SSB Universitas Riau U-15. JOM, 1-13.

Taufik. (2017). Hubungan Kecepatan dan Kekuatan Otot Tungkai Terhadap Kemampuan Shooting SSB Taruna Mandiri u-17 Pekanbaru. JOM, 2(1), 1-16.

Weda; Harmono, S. (2018). Hubungan Antara Kekuatan Otot Tungkai , Panjang Tungkai Dan Kelentukan Dengan Jauhnya Tendangan Pada Siswa Ekstrakurikuler Di SMA PGRI 4 Kediri Tahun 2017-2018. Prosiding Seminar Nasional IPTEK Olahraga, 31-38.

Wibowo, A. B. (2018). Hubungan Antara Kekuatan Otot Tungkai, Kekuatan Otot Perut, Dan Keseimbangan Dinamis Dengan Ketepatan PAssing Bola Umur 9-11 Tahun SSB Perseman Karanganyar Tahun 2018. Jurnal IImialh Spirit, 18(1), 16-26.

Zulfa, I. I., \& Kurniawan, A. W. (2020). Survei Kebugaran Jasmani Kelas VIII SMP Plus Asy-Syukur Kanigoro. Sport Science and Health, 1(3), 184-192. Retrieved from http://journal2.um.ac.id/index.php/jik/article/view/11343/4918 